\title{
Výzkum ve stádiu utváření
}

\author{
Martin Maryška
}

Páté doktorandské sympozium. Katedra divadelních studií Filozofické fakulty Masarykovy univerzity.

1. a 2. listopadu 2019. Univerzitní centrum MUNI, Telč.

Výroční páté doktorandské sympozium pořádané Katedrou divadelních studií na Filozofické fakultě Masarykovy univerzity se uskutečnilo o víkendu 1. a 2. listopadu 2019 v Univerzitním centru MUNI v Telči. Program setkání nebyl komponován kolem určitého tématu, přesto se lze pokusit vysledovat mezi desíti přednesenými př́spěvky víceméně patrné souvislosti.

Většinu prezentovaných výzkumů charakterizuje interdisciplinarita a interdiskurzivnost, a to pochopitelně zejména v těch případech, kdy se přispěvatelé zhostivší se role teoretiků vymezují vưči vlastní umělecké praxi, které se ujímají jako materiálu pro teoretické zhodnocení nebo ji reflektují ve smyslu povoláni umělce. Zájem doktorandů, jež vystoupili na sympoziu, zdá se poutají jevy, které obklopují, doprovázejí, ustavují nebo podmiňují to, čemu Ric Knowles ř́ká performance text (lze obecně ztotožnit s inscenací), a to spíše než tento performance text samotný (KNOWLES 2004). V intencích kulturního materialismu má kontext divadla, divadelnosti a divadelnictví materiální povahu. Performance text je spoluutvářen materiálními okolnostmi, za kterých vzniká, tj. je produkován, a podmínkami, za kterých je recipován. ${ }^{1}$

1 Do opozice ke kulturnímu materialismu Knowles staví sémiotiku rozvíjenou Pražskou strukturalitickou školou, s níž polemizuje o tom, zda materialistický kontext pomíjí, a významy dohledává pouze ve formální struktuře divadelního díla, které čte jako text. Materiální divadlo však může být analyzováno právě jen jako text. Už název publikace
Knowles daný koncepční rámec doporučuje k metodické analýze konkrétních divadelních počinů. $\mathrm{V}$ první části článku poslouží Knowlesův koncept jako vodítko při reflexi př́spěvků doktorandského sympozia. V druhé části bude osvětleno, co lze na produkci (umělecké divadelní praxi i teoretické činnosti) a potažmo recepci shledávat performativním. ${ }^{2}$

Materialistická i materiální extenze pojmu divadlo vyvažuje přístupy, které divadlo vykládaly z formalistických a strukturalistických pozic (KNOWLES 2004). Coby formy a struktury se chopil problematiky performance text př́spěvek Věry Velemenové „Rytmus a scénografie“; Katedra divadelní vědy, FF UK) jako jediný (autorka termín nepoužívá). Badatelku zajímalo, jak je v čase a prostoru scénografická forma strukturována rytmem. Podle Velemenové představují přestavby scény, proměny jevištního prostoru, technický a technologický problém a zároveň prostředek tvưrčího scénografického vyjádření, který programově uplatňuje takzvaná akční scénografie, jejíž vůdčí představitelé kultivovali smysl pro rytmus díky

signalizuje, že se Knowles pokouší o metodologické i předmětové smíření obou proudů v přístupu, který označuje jako „materialistická sémiotika“.

$2 \quad \mathrm{Na}$ sympozium jsem vystoupil $\mathrm{s}$ vlastním příspěvkem. Vzhledem $\mathrm{k}$ okolnosti, že příspěvek problematizoval téma performativity (divadelních plakátů) a zároveň recepci divadla, užiji téma performativity, resp. recepce divadla jako prizma pro tuto subjektivisticky koncipovanou reflexi. 
své operní zkušenosti. Autorka nadnesla v diskusi, že narozdíl od běžného života, kde jsou technologie vnímány jako odcizující člověka přirozenému rytmu žití, na divadle technologie podporují tvůrčí práci a soužití s rytmem. Z diskuse dále vyplynulo, že ač je problematika rytmu tradiční součástí divadelního myšlení (napřr. temporytmus, prozódie, rytmus pohybu, scénická hudba), hlubší metodické srovnání s muzikologickým pojetím představuje badatelskou př́ležitost.

Matěj Nytra ve svém příspěvku („Transparent-text a informace ve vizuálním kódu. Philippe Quesne, Pražské Quadriennale, Farm Fatale“; Divadelní fakulta, JAMU) představil svou připravovanou disertaci, v níž se zaměřuje na problém textu a textuality na divadle. Text pro divadlo (jak překládá Theatertext podle Poschmannové) zkoumá na materiálu a v kontextu současného postdramatického divadla. Zabývá se texty scénicky užitými na transparentech a nápisech ve společensky angažovaných performancích a instalacích Philippa Quesneho Mikrokosmos a Farm Fatal, jež referují ke společenskému kontextu divadla.

Vzhledem k tomu, že se ve své disertační práci zabývám podobným tématem jako Matěj Nytra, dovolím si předložit úvahu, k níž mě kolegův př́íspěvek navedl. Když anotace v katalogu $P Q$ charakterizuje instalaci jako divadlo objektů, nebylo by na místě hovořit též o divadle textů? V klimaticky rozvráceném dystopickém světě, který Quesneho dílo předvídá, už nebude nic k obrazu božímu a pohled na svět nebude snesitelný, text pak zůstane posledním útočištěm slibujícím nový začátek. Bereme tedy s povděkem reprezentaci světa, ve kterém nic mimo text neexistuje, ${ }^{3}$ protože nad textem si držíme kontrolu. Obraz má moc, protože „řekne více než tisíc slov“, ale jedno slovo může vyvolat právě tolik obrazů v mysli. Nadto může coby existenční model, s výpůjčkou od Iva Osolsobě, pojmout celou existenci (OSOLSOBĚ 2002). Obraz se rozkládá mezi ničím a vším; na krajích jsou podle Osolsobě takzvané existenční modely a token:token modely, které se podobají reprezentovanému bud' jen tím, že prostě existují, resp. jsou s reprezentovaným totožné. Takové modely jsou pak zároveň nejlepší a nejhorší: na jednu stranu (a pól ikoničnosti) je jazyk nejhorší existenční model v tom smyslu, že slovo a jeho denotát „nemají pranic společného“ (OSOLSOBĚ 2020: 241); na druhou stranu je jazyk nejlepším modelem, když v režimu token:token modeluje jinou přímou řeč. Opírám se o představu, že myšlenky nacházejí svůj nejlepší výraz, model či extenzi v řeči. Angažované divadlo je tedy divadlem idejí a textů zaprvé do té míry, do jaké se potřebuje angažovat $\mathrm{v}$ jazykovém (ideologickém) diskurzu (text je součástí kontextu), a zadruhé do té míry, do jaké je nedůvěřivé $\mathrm{k}$ (mimetickým) obrazům. Estetika sloganů, nápisů, transparentů i současná typografie je ikonoklastická a zároveň ideologická (je-li jazyk z podstaty ideologický). Těží z toho, že slovo může být vším a ničím: může komunikovat názor, ale není názorné, ačkoli může být obrazotvorné. O současnosti se mluví jako o epoše obrazů, obrazy ale kupodivu text nevypudily, naopak se text integroval do vizuálního pole. Transparent, cedule na tyči, je slovo, které má ten, komu je upřen přístup k mikrofonu. Může se však postavit před fotoaparát nebo kameru. Je to slovo, které se adaptovalo na svět obrazů, stalo se tak obrazem, aby nezaniklo v hluku. 
Ve svém vlastním příspěvku (Martin Maryška: „Svolávám všechny diváky aneb Performativita divadelních plakátů“; Seminář estetiky, FF MU) jsem na příkladu tvorby Borise Myslivečka osvětlil, že podobnou formu existence jako transparenty nabyl i divadelní plakát. Znějící slovo principála svolávajícího kolemjdoucí se vtělilo do obrazu, který je vylepen, performován výlepem, jako plakát. Je příznačné, že to byl právě plakát divadelní - plakát na akce performativního umění - ve kterém se obraz a text slil v novou vizuální formu - reklamu, která od 19. století formuje vizuální vnímání moderního člověka.

Imerzivní divadlo lze uchopit jako estetický problém, Ivo Kristian Kubák („Imerzivní principy v divadelní režii, dramaturgii a scénografii“; Divadelní fakulta, AMU) však pojem explikoval vylíčením atypických okolností produkce a tvorby projektu $C A M P Q$, jehož byl autorem v rozsáhlé autorské kolaboraci. Produkce a tvorba podle něj připomíná vývoj nové technologie: Divadelní povídka formuluje námět a obrysy diváckého zážitku, takzvanou mašinérii vizualizuje diagram o časové a prostorové ose, na kterých jsou vyneseny scénické situace dále rozpracované ve scénáři. Povaha produkčních procesů podle autora příspěvku vybízí $\mathrm{k}$ přehodnocení konceptu uměleckého autorství a autorství celkově: definice formátu jako světa divácké dramaturgie přisuzuje autorskou autoritu v procesu recepce divákovi. K problematice diváckého zážitku se stočila také diskuse, jejíž stěžejní otázkou bylo, jakou relevanci má kategorie ideálního diváka, jehož pozici obvykle zaujímá režisér.

Když Kubák popisuje formát $C A M P Q$ jako scénografickou instalaci, váže $\mathrm{k}$ sobě dva pojmy, které tradičně přináležejí ke dvěma relativně rozdílným diskurzům: k divadlu a k výtvarnému umění. Rozdíly a průniky mezi divadlem a výtvarným uměním coby autonomními diskurzy, sociálními poli, estetikami, poetikami a uměleckými praxemi, jak se vyjevují na konceptu performance, problematizuje práce Jany Orlové („Performance (art) a divadlo“; Katedra teorie a dějin umění AVU). Ta ve svém příspěvku nastínila, že performing arts, tj. performativní umění, se zajímají o performativitu teoreticky, nicméně přehlíží performance art, tj. umění performance, jako uměleckou praxi. Performance art podle ní na druhou stranu promítá do performing arts zavádějící představy o divadle a divadelnosti, totiž že divadlo je „teatrální, umělé a neautentické“. ${ }^{4} \mathrm{Na}$ závěr příspěvku se výzkumnice dotkla otázky hmotných podmínek umělecké produkce a divácké recepce, když připomněla divadelní konvence jako konstitutivní aspekt definice divadla. ${ }^{5}$

Sandra Polovková („Pravidelná a projektová dramaturgia“; Divadelná dramaturgia, réžia a teatrológia, Akadémia umení, fakulta dramatických umení) promluvila o projektu Slovenského národního divadla Natálka ${ }^{6}$ v kontextu prolínání projektové dramaturgie a repertoárové dramaturgie. Nabídnu srovnání s imerzivním divadlem: zatímco v jeho případě vstupují diváci

4 Podle přednášky Jany Orlové na konferenci Akademie múzických umění Teritoria uměni 2019, 6. ročník vědecké konference doktorandů uměleckých vysokých škol, 18. ř́ijna 2019, Divadlo Inspirace, Praha.

5 Dle mého názoru se z estetického hlediska bude rozlišení obou forem lámat na rozdílné povaze diváckého zážitku.

$6 \quad$ Natálka je inscenace SND na motivy kauzy popálení romského děvčátka při žhářském útoku na dům její rodiny ve Vítkově v roce 2009. Tuto inscenaci SND uvádí bezplatně pro střední školy a po představení následuje diskuse na téma extremismu. 
do cizího alternativního světa, v případě projektu Natálka divadlo vstoupilo do domácího prostředí školy. Performativní studia by přispěla $k$ pochopení vzrušené společenské debaty a dění kolem projektu nahlédnutím záležitosti např́klad skrze teorii komunikativního jednání Jürgena Habermase nebo symbolického jednání. Projektová dramaturgie reaguje na politicky artikulovanou společenskou potřebu. K otázce materiálních podmínek se hodí připomenout, že v rámci grantových výzev se stanovují tematické priority vycházející z hodnotových premis dárců, kdy je projekt chápán jako prostředek řešení určitého společenského problému. Hodnotový systém společnosti, jak je například v obecnosti deklarován v Ústavě, se promítá také do povinné školní četby a je konfrontován, když prostřednictvím dramat a děl na náměty z ní se dramaturgie slovenských divadel včetně Slovenského národního divadla snaží oslovit školní a studentské publikum.

Příspěvky teatrologů Jiřiny Hofmanové, Kataríny Cupanové a Martina Hanouška spojuje historiografické téma a metodologie; rovněž v jejich případě bylo středem zájmu okolí (produkce či recepce) divadla. Okolnost, že samotné uvedení hry je jistým druhem performativního, politického aktu, odhaluje také výzkum Jiřiny Hofmanové („Proměny čechovovského diskurzu 1945-1968“; Katedra divadelních studií, FF MU) zaměřený na čechovovský diskurz v Československu od konce světové války po začátek normalizace. Na materiálu knižních doslovů a předmluv, učebních textů, článků, studií či monografií badatelka mapuje filozofické a politické koncepty a narativy vázané podle politické situace a potřeby na osobu Čechova a jeho dílo. Zájem o texty pro divadlo či texty o divadle se odrazil rovněž v prríspěvku teatrolo- ga Martina Hanouška („Die Entführung aus dem Serail (Únos ze serailu) v rukopisu Scenarien-Buch Václava Tháma“; Kabinet pro studium českého divadla IDU) který zkoumá zápis divadelního pojetí prvního dějství Mozartova singspielu Únos ze serailu v rukopisu Scenarien-Buch Václava Tháma. Katarína Cupanová („Dráma slovenskej moderny“; Ústav slovenské literatury při Slovenské akademii věd) podniká historiografický výzkum, v němž se zaměřuje na modernistické tendence v dramatech Josefa Gregora Tajovského, tímto směrem byl ovlivněn při pobytu v Praze při setkání s bratry Mrštíky a Gabrielou Preissovou, a polemizuje s jeho kategorickým zařazením do proudu lidového a realistické dramatiky.

\section{Prekérnost, produktivita a performativita doktorandské práce}

Anglická slova performance a production (na rozdíl od jejich teatrologických ekvivalentů v češtině) konotují pojmy z oborů ekonomie a sociologie. Není patrně náhodou, že třetí z ramen Knowlesova modelu, tj. recepce divadla a divadelní publikum, se stává předmětem zájmu teatrologů v 70. letech 20. století (BENNETT 1990). Jde o dekádu, ve které se podle Svena Lüttickena rozmohla takzvaná new labour (LÜTTICKEN 2012). Performance je v definici Richarda Schechnera neproduktivní činnost, a právě neproduktivní činnost je náplní new labour a její podstatou je general performance.

Lütticken poukazuje na to, že performativní obrat v charakteru práce vychází ze stejných předpokladů, přesněji přímo estetických východisek jako performance 
art: základy general performance položila "generalisation of artistic performance " (LÜTTICKEN 2012). Podle Lüttickena: „General performance is labor beyond measure; it is the qualitative performance of time rather than its quantitative use" (LÜTTICKEN 2012). Jelikož, co je na práci měřitelné, například počet výrobků za den, zastane automatizovaná linka, roboti nebo levná pracovní síla; zbývá performance kompetencí včetně takzvaných soft skills. Tou měrou, jakou jsou soft skills determinované osobnostními danostmi, splývá práce se sebeperformancí. Performativita je tedy obecná nejen na úrovni společnosti, ale i jednotlivce.

Schechner definoval performanci též jako „showing doing“ (SCHECHNER 2006: 28). ${ }^{7} \mathrm{~V}$ situaci general performance se „doing “ musí ukazovat neustále. Práci pojatou v tomto režimu jako povolání nelze zanechat po vyměřeném čase. Například grafický designér, jak svou situaci reflektuje Tereza Rullerová, není grafickým designérem, jen když dělá grafický design, ale nadto musí „showing doing“ při nejrůznějších kulturních performancích, společenských akcích jako jsou vernisáže či konference (RULLEROVÁ 2015).

Do výčtu performativních forem zahrnuje Schechner art-making process, splývající významnou měrou s divadelní produkcí. ${ }^{8}$ Produkce a performance tedy

7

Čerpám z (LANGHANS 2018).

8 "These deep structures include preparations for performance both by performers (training, workshops, rehearsals, preparations immediately before going on) and spectators (deciding to attend, dressing, going, settling in, waiting) and what happens after a performance. The ways people cool off and the sometimes extended aftermath of performances are less studied but very important. Cooling off includes getting performers and spectators out of, or down from, the performance; putting the performance space and implements to rest; the aftermath includes spreading the news about performances, evaluating them - even writing books about them - and in many ways determining how v jistém smyslu koexistují a nevylučují se: "The entire operation changes its shape, what it is, according to various modes of production " (SCHECHNER 2003: 12). Práce, ukáže-li se, vystaví-li se na odiv, se stává o něco více performancí, aniž by se nutně stala méně produktivní.

New labour stvořila prekariát, který Guy Standing definuje pomocí př́íhodného, dalo by se říct přímo performativního výrazu jako „a class in the making“ (STANDING 2011) a dále popisuje v rozhovoru pro časopis A2LARM:

Druhým, velmi důležitým aspektem je, že pokud jste součástí prekariátu, musíte vykonávat činnost, která vůbec prací není. Tedy spoustu práce, která se nepočítá, není respektována, není v žádných statistikách a ani netvoří součást politické rétoriky. Ale pokud jste v prekarizované třídě, tak dobře víte, že ve svém volném čase musíte udělat spoustu práce, kterou nikdo neocení. A pokud ji neuděláte, doplatíte na to. (SKÁLA a UHNÁK 2016)

General performance je typická také pro další třídu, kterou Standing pojmenovává proficians:

Ztělesňují romantický model dnešní společnosti. Nechtějí zaměstnanecké jistoty a výhody, protože jsou na to př́liš chytří. V̌sechny své výrobní prostředky a schopnosti mají v počítačové brašně a v kapsách u kalhot, musí se neustále sítovat s dalšími lidmi a pracují na krátkodobých projektech. (SKÁLA a UHNÁK 2016)

specific performances feed into ongoing systems of social and aesthetic life." (SCHECHNER 2003: 18) 
$\mathrm{V}$ řečeném smyslu rovněž práce doktoranda obnáší vedle skutečné produktivní práce sebeperformanci při přiležitostech jako například sympozium doktorandů. Nekompromisní „publish or perish“ reflektuje, v čem není výzkumná, resp. publikační činnost produkcí, ale performancí. Aby výzkumník byl a zůstal výzkumníkem, musí svou přítomnost opakovaně připomínat odborné veřejnosti. Spíše než solidní výrobek je článek výskyt, který musí být někde vykázán, aby byl prokázán. Autoři nicméně dobře vědí, že pokud je kolem publikační činnosti něco ryze produktivního, nikoli performativního, pak je to vlastní psaní článků a jejich editace a korektury, doslova jejich strojní výroba. Produktivní dimenzi výzkumné práce odráží hantýrka biologů či chemiků; ti články nepíší, ale „pipetuji““.

Nerealizujeme práci, ale realizujeme sebe prací či dokonce práce realizuje nás, jako by performance nebyla jen „showing doing“, ale rovněž „showing doing being“. „Doing“ je věcí procesu výroby představení čili divadelní produkce. V současné kulturní praxi se ukazuje, vystavuje, scénuje dříve zákulisní produkční práce. Správa těchto performativních scén tvoří náplň práce, tj. performanci jako výkon úkonů, a obsah povolání, tj. performanci jako výkon povolání, specialistů public relations či konkrétněji správců sociálních sítí. Jde o ukázkovou new labour založenou na general performance, at už mají blíže k prekariátu v případě částečných úvazků a smluv v neziskovém a kulturním sektoru, nebo k profesians v kreativních průmyslech a komerčním odvětví.

\section{Bibliografie}

BENNETT, Susan. 1990. Theatre Audiences: A Theory of Production and Reception. London/New York: Routledge, 1990.

DERRIDA, Jaques. 1967. De la grammatologie. Paris: Éditions de Minuit, 1967.

KNOWLES, Richard Paul. 2004. Reading the Material Theatre. Cambridge: Cambridge University Press, 2004.

LANGHANS, Martin. 2018. Soudní proces jako rituál? Theatralia 21 (2018): 1: 33-52. Brno: Masarykova univerzita, 2018.

LÜTTICKEN, Sven. 2012. General Performance [online]. e-flux, (31. 1. 2012) [citováno dne 27. 12. 2019]. Dostupné online na: < http:/ / www.e-flux. com/ journal/general-performance/>

SKÁLA, Jiří a Tomáš UHNÁK. 2016. Prekariát: společenská třída $\mathrm{v}$ utváření : Rozhovor s ekonomem Guyem Standingem. A2LARM (27. 05. 2016) [citováno dne 27. 12. 2019]. Dostupné online na: <https://a2larm. cz/2016/05/prekariat-spolecenska-trida-v-utvareni/>

SCHECHNER, Richard. 2003. Performance Theory. $2^{\text {nd }}$ ed. London/New York: Routledge, 2003.

SCHECHNER, Richard. 2006. Performance Studies: an Introduction. $2^{\text {nd }}$ ed. New York: Routledge, 2006.

STANDING, Guy. The Precariat: The New Dangerous Class. New York: Bloomsbury Academic, 2011.

OSOLSOBĚ, Ivo. 2002. Dva póly ikoničnosti. In Ivo OSOLSOBĚ. Ostenze, hra, jazyk: Sémiotické studie. Brno: Host, 2002: 239-289.

RULLEROVÁ, Tereza. 2015. Action to Surface [online]. Diplomová práce [citováno dne 27. 12. 2019]. Dostupné online na: 〈https://www.therodina.com/actiontosurface/index.html> 